\title{
ECOFRIENDLY MANAGEMENT OF MUSTARD APHID Lipaphis erysimi (KALT), ON RAPESEED IN GOKULESHWOR, BAITADI
}

\author{
S. Adhikari ${ }^{1}$, M. Lamichhane ${ }^{1}$, P. Sapkota ${ }^{1}$, S. Parajuli ${ }^{1}$, N.B. Singh ${ }^{2}$ and D. Ghimire ${ }^{2}$
}

\begin{abstract}
Rapeseed (Brassica campestrisL. var. toria) is a bright yellow flowering member of family Brassicaceae cultivated mainly for its oil rich seed. It is third largest source of vegetable oil in world. Mustard aphid, Lipaphis erysimi (Kalt) is the major limiting factor in the production of rapeseed. An experiment was conducted to evaluate the management practices of mustard aphid during Rabi season in 2017/018 at Gokuleshwor, Baitadi. A field experiment was laid out in a randomized complete block design $(R C B D)$ with 7 treatments replicated thrice. The study revealed that the Altineem was effective for managing the mustard aphid followed by Bacillus thuringiensis. This information could be helpful for mustard aphid management and utilizing Altineem in eco-friendly management of Lipaphis erysimi (Kalt).
\end{abstract}

Keywords: Altineem, Bacillus thuringiensis, ecofriendly, mustard aphid, rapeseed

\section{INTRODUCTION}

Rapeseed (Brassica campestris L. var. toria) is a bright yellow flowering member of family Brassicaceae cultivated mainly for its oil rich seed. It is the third largest source of vegetable oil in world. It is an annual crop and usually herb with long and tapering root. Leaves are glabrous, hairy and pale green to dark green in color. Flower is yellow to pale yellow in color with four sepals and four petals with tetradynamous stamens. Seed is brown to yellow in color depending on variety. Rapeseed contains $40-45 \%$ oil and $24 \%$ protein. It is considered safe for people with weak heart and suffering from chronic diseases. Rapeseed and mustard are important oilseed crops and contribute major source of edible oil in our country. It is grown in 173,254ha with annual production of 152,263 mt. in our country (MoAD, 2015). With the demand for oilseed running of supplies, the production trends have been unsatisfactory due to attack of various insect- pests. More than $\mathbf{4 5}$ species of insect pests infest mustard crop in the world which include about dozen species as major pests (Parwar and Sachan, 2004).

1 Gokuleshwor Agriculture and Animal Science College.

Corresponding Author:sarmilaa876@gmail.com

2 Institute of Agriculture and Animal Science, Tribhuvan University, Nepal 
Mustard aphid, Lipaphis erysimi (Kalt) (Homoptera: Aphididae) is the major limiting factor in the production of rapeseed. It cause severe damages to the plant by sucking plant sap from tender shoots of the plants in the beginning and later sucks the sap from tender pods. The infested plants become weak and stunted. Several infested plants do not flower at all. The excessive excretion of honey dew by the aphid results in the photosynthetic activity of the leaves. Under different agro-climatic condition the losses due to this pest may be up to $97.6 \%$ in its yield under unprotected condition (Patel et al., 2004).

Insect pest has always become the main topic for farmers. More than three dozen of pests are known to be associated with various phenological stages of rapeseed-mustard crops. Among these pests, mustard aphid (Lipaphis erysimi Kalt.) is considered one of the devastating insect pests for its successful production (Bakhetia and Sekhon, 1989).

Mustard aphid, Lipaphis erysimi (Kalt.) was the most serious insect-pest of rapeseed-mustard and responsible for causing the yield losses ranging from 35.4 to 96 percent depending upon weather condition (Das, 2014). In Nepal, yield loss up to $35 \%$ was recorded in Brassica campestris var. toria by insect-pests (NORP, 1990). Farmers used to apply high dose of chemicals as well as banned chemicals. Use of chemicals for insect management leads to problem of environment pollution, pest resurgence, harmful effects on pollinators and natural enemies and also affects human health. Realization of negative impacts of harmful chemical pesticides leads to the search of an eco-friendly management of insect pests which, includes microbial approaches with antagonistic entomopathogenic fungi and botanical pesticides as best alternatives (Bakhetia and Sekhon, 1989).

Mustard aphids are small, soft-bodied, pearl shaped insects that have a pair of cornicles projecting out from the $5^{\text {th }}$ or $6^{\text {th }}$ abdominal segment. Both the nymphs and adult suck the sap from leaves, succulent tender stem, inflorescence and pods. The heavily infested plant remains dwarf and stunted and do not put forth new branches. The petals of open flowers turn prematurely white and the pod shrivel up and seed do not develop under severe infestation. Aphids also secrete a sweet liquid called honey dew on which black mold develops giving the plants a blighted appearance. The mould adversely affects the normal physiological activities of plant. Cloudy and moist weather is favorable for the multiplication of this pest. In severe infestation plants may die (Kafle, 2015). 


\section{MATERIALS AND METHODS}

A field experiment was carried out at Gokuleshwor Agriculture and Animal Science Collage, Gokuleshwor, Baitadi. Baitadi district lies in high hills of Nepal at an elevation of $700 \mathrm{~m}$ above mean sea level and lies between $27^{\circ} 30^{\prime}$ North latitude and $83^{\circ} 27^{\prime}$ East longitude. Previously barren land was selected for our research. The longitudinal layout of field was facing with east-west direction. The experiment field was cleaned removing all weeds and ploughed on Decenber, 2017 by M.B. plough and was levelled with the help of spade and rake. The soil was pulverized in the fine particles for ensuring the better growth of the rapeseed.FYM was applied @4 doko(approx.20kg) during land preparation. Fertilizer was applied at recommended dose 60:30:30 NPK kg/ha for rapeseed (MoAD, 2015). Urea @ 2.8gm/plot, DAP @ 2.6gm/plot MOP @ $1 \mathrm{gm} /$ plot were applied as basal dose of plant nutrients. The experiment was laid out in randomized complete block design (RCBD). The experiment included seven treatments and three replications. The plot size of each treatment was $2 \mathrm{~m} \times 2.5 \mathrm{~m}\left(5 \mathrm{~m}^{2}\right)$. The distance maintained between two plots was $0.5 \mathrm{~cm}$ and each replication was separated by $1 \mathrm{~m}$. Local variety of rapeseed was broadcasted @ 3gm/plot on Janaury, 2018. Germination was observed after 10 days of broadcasting. For ensuring proper growth and development intercultural operations like thinning out, weeding and irrigation were carried out at regular interval. Thinning out was done when the plant population seems dense for reducing the competition for nutrient, space, light and for production of healthy and bigger pod. Weeding was done manually to reduce the effect on growth and development on rapeseed. Irrigation was provided on regular interval by observing the soil moisture content. Our treatments Altineem, Bacillus thuringiensis and Beauveria bassiana were easily available in market in useable form. For Artemesia extract, fresh leaves of Artemesia were fermented with sugar solution. After 15 days, it was ready to use. Collected old cow urine and powered mustard cake was used in field. Weather information was not recorded during this period (Table 1).

Table 1: Treatment combination

\begin{tabular}{ll}
\hline Treatmentsymbol & Treatments details \\
\hline T1 & Bacillus thuringiensis $\left(2.5 \mathrm{~g} / \mathrm{l} \mathrm{H} \mathrm{H}_{2} \mathrm{O}\right)$ \\
$\mathrm{T} 2$ & Beauveria bassiana $(2.5 \mathrm{ml} / \mathrm{l} \mathrm{H} \mathrm{O})$ \\
$\mathrm{T} 3$ & Altineem $\left(2.5 \mathrm{ml} / \mathrm{l} \mathrm{H} \mathrm{H}_{2} \mathrm{O}\right)$ \\
$\mathrm{T} 4$ & Cow urine $(250 \mathrm{ml} / \mathrm{l} \mathrm{H} \mathrm{O})$ \\
$\mathrm{T} 5$ & Artemesia $\left(250 \mathrm{ml} / \mathrm{l} \mathrm{H} \mathrm{H}_{2} \mathrm{O}\right)$ \\
$\mathrm{T} 6$ & Mustard cake $(25 \mathrm{~kg} / \mathrm{ha})$ \\
$\mathrm{T} 7$ & Control (untreated) \\
\hline
\end{tabular}


Observations were taken from $10 \mathrm{~cm}$ apical central shoot of inflorescence from 10 randomly selected plants of each plot. Both pre-treated and post-treated observation was taken for mustard aphid, lady bird beetle, and honeybee. First, the collected data were entered in excel sheet then it was analyzed with the help of statistical tool R-3.2.2.

\section{RESULTS AND DISCUSSION}

Among different biological insecticides used under field condition to control the mustard aphid, altineem was recorded as most effective against mustard aphid. The similar result was found by Singh and Lal (2012). They were selected seven different botanical leaves, neem leaf extract (Azadirachta indica), Congress grass leaf extract (Parthenium hysterophorus) Lemmon grass leaf extract (Cymbopogon citrates), Bhang leaf extract (Cymbopogon citrates), Garlic leaf extract (Allium sativum), Punch phuli leaf extract (Lantana camera) and Marigold Leaf extract (Tageteserecta) on mustard aphid were tested. The botanical extracts showed varying effect on aphid population and neem leaf extract (T1) inflicted consistently the maximum level of aphid mortality (77.33\% and $71.76 \%$ ) followed by Punch phuli leaf extract $(74.35 \%$ and $70.96 \%)$ and Garlic leaf extract $(73.19 \%$ and $62.17 \%)$ on 7 th day after spray. All the treatments of plant leaf extracts showed insecticidal activity, but Indian neem leaf extract followed by Punch phuli leaf extract and Garlic leaf extract reduced the aphid population to a great extent. The result also found the microbial insecticides such as Bacillus thuriengensis and Beauveria bassiana also effective to control the mustard aphid in rape seed. This result also supported by Ujjan and Shahzad (2014) studied the insecticidal potential of the entomo-pathogenic fungal (EPF) strain of Beauveria bassiana (Bals. -Criv) Vuill and insecticide Imidacloprid to mustard aphid (MA) at field conditions. The Beauveria bassiana strain PDRL1187 caused 50\% mortality (LT50 value $=$ median lethal time) of adult MA population after 6.4 days, when sprayed on insect population $6.3 \times 1012$ spores per acre. The insecticide, $10 \mathrm{~g}$ per acre, caused the insect mortality increased with application of EPF and insecticide, at field trials. The study confirmed that with LT50 value 3.2 days. Along with the pest mortality, the seed yield of mustard plant (canola), strain is effective against mustard aphid under field conditions. This result is also supported by Kafle (2015). The field experiment showed that the highest reduction of Lipaphis erysimi (Kalt.) was achieved in chemical insecticide, Dimethoate (Rogor $30 \mathrm{EC}$ ) followed by Botanical (Derisom- neem based pesticide) but these two treatments were statistically at par during almost all the spray times. Thus, Derisom (botanical) might be the best option in eco-friendly management of Lipaphis erysimi (Kalt.). The obtained result shows the both significance as well 
as non-significance at different date. Before treatment/spray, three days after first spray and three days after second spray showed the non-significant. Regarding the aphid population, before treatment the aphid population ranged from 15.70 to 28.90 aphids/plant. On three days after first spray the aphid population ranged from 13.4 to 26.7 aphids/plant where the lowest population was recorded from Bacillus thuriengensis (13.40 aphids/plant). There was significant results recorded at 6 DAFS (13.96 to 37.46 aphids/plant), 9DAFS (12.96 to 59.10 aphids/plant), 6 DASS (10.93 to 76.60 aphids/plant), 9 DASS ( 9 to 74.23 aphids/plant), 3 DATS (7.36 to 129.20 aphids/plant), 6 DATS (3.30 to 174.93 aphids/plant) and 9 DATS (1.53 to 245.36 aphids/plant) Table 2, Table 3 and Table 4.

Table 2: Number of aphid population before and after treatment

\begin{tabular}{lcccc}
\hline \multicolumn{1}{c}{ Treatments } & Before trt. & 3 DAFS & 6 DAFS & 9DAFS \\
\hline Bacillus thuringiensis(T1) & $15.70 \mathrm{a}$ & $13.40 \mathrm{a}$ & $13.96 \mathrm{~b}$ & $21.03 \mathrm{~b}$ \\
Beauveria bassiana(T2)s & $28.90 \mathrm{a}$ & $25.63 \mathrm{a}$ & $32.60 \mathrm{ab}$ & $30.16 \mathrm{ab}$ \\
Altineem (T3) & $17.76 \mathrm{a}$ & $19.10 \mathrm{a}$ & $14.36 \mathrm{~b}$ & $12.96 \mathrm{~b}$ \\
Cow urine (T4) & $22.50 \mathrm{a}$ & $21.23 \mathrm{a}$ & $20.76 \mathrm{ab}$ & $43.50 \mathrm{ab}$ \\
Artemesia extract (T5) & $19.10 \mathrm{a}$ & $18.46 \mathrm{a}$ & $18.16 \mathrm{ab}$ & $29.76 \mathrm{ab}$ \\
Mustard cake (T6) & $19.10 \mathrm{a}$ & $24.03 \mathrm{a}$ & $20.40 \mathrm{ab}$ & $18.13 \mathrm{~b}$ \\
Untreated plot (T7) & $26.86 \mathrm{a}$ & $26.70 \mathrm{a}$ & $37.46 \mathrm{a}$ & $59.10 \mathrm{a}$ \\
Mean & 21.41 & 21.22 & 22.53 & 30.66 \\
Test of Significance & $\mathrm{NS}$ & $\mathrm{NS}$ & $*$ & $* *$ \\
CV (\%) $^{*}$ & 10.0 & 10.0 & 14.0 & 6.9 \\
LSD $_{0.05}$ & 11.55 & 9.40 & 14.04 & 21.63 \\
\hline
\end{tabular}

${ }^{*},{ }^{* *}, \mathrm{NS}$ indicate significant at $\mathrm{P}<0.5, \mathrm{P}<0.05$ and non significant.

Table 3: Number of aphid populations after second spray

\begin{tabular}{lccc}
\hline \multicolumn{1}{c}{ Treatments } & 3DASS & 6DASS & 9DASS \\
\hline Bacillus thuringiensis(T1) & $15.00 \mathrm{a}$ & $12.60 \mathrm{~b}$ & $8.60 \mathrm{~b}$ \\
Beauveria bassiana(T2) & $47.43 \mathrm{a}$ & $44.00 \mathrm{ab}$ & $43.50 \mathrm{ab}$ \\
Altineem (T3) & $14.13 \mathrm{a}$ & $10.93 \mathrm{~b}$ & $9.00 \mathrm{~b}$ \\
Cow urine (T4) & $44.20 \mathrm{a}$ & $31.00 \mathrm{~b}$ & $43.70 \mathrm{ab}$ \\
\hline
\end{tabular}




\begin{tabular}{|c|c|c|c|c|}
\hline Artemesia extract (T5) & $28.60 \mathrm{a}$ & \multicolumn{2}{|c|}{$26.93 b$} & $23.90 \mathrm{~b}$ \\
\hline Mustard cake (T6) & $18.40 \mathrm{a}$ & \multicolumn{2}{|c|}{$16.53 \mathrm{~b}$} & $14.36 \mathrm{~b}$ \\
\hline Untreated plot (T7) & $50.06 \mathrm{a}$ & \multicolumn{2}{|c|}{$76.60 \mathrm{a}$} & $74.23 \mathrm{a}$ \\
\hline Mean & 31.11 & \multicolumn{2}{|c|}{31.22} & 31.04 \\
\hline Test of Significance & NS & \multicolumn{2}{|c|}{ ** } & ** \\
\hline $\mathrm{CV}(\%)$ & 13.6 & \multicolumn{2}{|c|}{14.2} & 27.6 \\
\hline $\mathrm{LSD}_{0.05}$ & 25.82 & \multicolumn{2}{|c|}{26.21} & 25.25 \\
\hline \multicolumn{5}{|c|}{ **and NS indicate significant at $\mathrm{P}<0.05$ and non-significant. } \\
\hline Treatments & 3DATS & 6DATS & 9DATS & Average \\
\hline Bacillus thuringiensis(T1) & $5.66 \mathrm{~b}$ & $3.66 \mathrm{~b}$ & $3.56 \mathrm{~b}$ & $11.32 c$ \\
\hline Beauveria bassiana (T2) & $20.33 \mathrm{~b}$ & $16.60 \mathrm{~b}$ & $14.73 \mathrm{~b}$ & $30.39 \mathrm{~b}$ \\
\hline Altineem (T3) & $7.36 \mathrm{~b}$ & $3.30 \mathrm{~b}$ & $1.53 \mathrm{~b}$ & $11.05 c$ \\
\hline Cow urine (T4) & $31.20 \mathrm{~b}$ & $22.30 \mathrm{~b}$ & $16.00 \mathrm{~b}$ & $29.64 \mathrm{~b}$ \\
\hline Artemesia extract (T5) & $17.13 \mathrm{~b}$ & $14.70 \mathrm{~b}$ & $9.66 \mathrm{~b}$ & $20.64 \mathrm{bc}$ \\
\hline Mustard cake (T6) & $10.60 \mathrm{~b}$ & $7.90 \mathrm{~b}$ & $3.63 \mathrm{~b}$ & $15.31 \mathrm{bc}$ \\
\hline Untreated plot (T7) & $129.20 \mathrm{a}$ & $174.93 \mathrm{a}$ & $245.36 \mathrm{a}$ & $90.05 \mathrm{a}$ \\
\hline Mean & 31.64 & 34.77 & 42.07 & 29.8 \\
\hline Test of Significance & $* * *$ & $* * *$ & $* * *$ & $* *$ \\
\hline CV (\%) & 8.0 & 7.2 & 16.4 & 9.2 \\
\hline $\mathrm{LSD}_{0.05}$ & 39.37 & 19.88 & 33.51 & 15.30 \\
\hline
\end{tabular}

***,** indicate significant at $\mathrm{P}<0.005$ and $\mathrm{P}<0.05$.

DAST: Days after first spray, DASS: Days after second spray, DATS: Days after third spray, CV: Coefficient of variance, LSD: Least Significant Difference

\section{CONCLUSION}

The research related to the management of aphid population in rapeseed crop by using different non-chemical pesticides was conducted at GAASC. Aphid population in rape seed was significantly different among the treatments. The highest aphid population was recorded from untreated plot $(90.05$ aphids/plant) whereas lowest population of aphids was recorded from the altineem (11.05 aphids/plant) which was significantly lower than from 
untreated plot. From the results it was clear that the altineem was the most effective means for the management of mustard aphids in rapeseed followed by Bacillus thuriengensis and Beauveria bassiana.

\section{ACKNOWLEDGEMENT}

The authors would like toextend sincere thanks to Gokuleshwor Agriculture and Animal Science College, Baitadi for funding the project. Help received from GAASC family involved in this project are highly acknowledged.

\section{REFERENCE}

Bakhetia, D. R. C. and B. S. Sekhon. 1989. Insect-pests and their management in rapeseed-mustard. Journal of Oil seeds Research. 6:269-299

Das, P. C. 2014. Oilseed crops of India. Kalyani publishers. pp no. 8-41.

Kafle, K. 2015. Management of mustard aphid, Lipaphis erysimi (Kalt.) (Homoptera: Aphididae). Int. J. Appl. Sci. Biotechnol., 3(3): 537-540.

MoAD. 2015. Statistical information on Nepalese agriculture. Government of Nepal, Ministry of Agricultural Development, Monitoring, Evaluation and Statistical Division, Agri-statistic section, Singhdarbar, Kathmandu, Nepal.

NORP.1989/90. Annual report. National Oilseed Research Program, Nawalpur, Sarlahi, Nepal. 123p.

Parwar, J. P. and G. C. Sachan. 2004. Bio-efficacy of entomopathogenic fungi against mustard aphid: Lipaphis erysimi (Kalt) on Brassica compestris. J. Aphidology, 18:5-10.

Patel, S. R., A. K. Awasthi and R. K. S. Tomar. 2004. Assessment of yield lossess in mustard (Brassica juncea L.) due to mustard aphid (Lipaphis erysimi Kalt) under different thermal environments in Eastern Central India. Applied Ecology Environmental Research, 22(1):1-15.

Singh, A.K. and Lal, M. N. 2012. Bio-efficacy of some plant leaf extracts against mustard aphid, Lipaphis erysimi Kalt. on Brassica campertris. Asian Journal of Bio Science, 7(2): 159-162.

Ujjan,A.A. and S.Shahzad. 2014. Insecticidal potential of Beauveria bassiana strain PDRL 1187 and Imidacloprid to mustard aphid (Lipaphis erysimi) under field conditions. Pakistan J.Zool., 46(5):1277-1281. 